\title{
The Relationship between Brand Club Personalities, Trust and Brand Loyalty in Fans of Persepolis FC
}

\author{
Hamid Roudbari ${ }^{1}$, Alireza Elahi ${ }^{1} \&$ Hossein Akbari Yazdi ${ }^{1}$ \\ ${ }^{1}$ University of Kharazmi, Kharazmi, Iran \\ Correspondence: Hamid Roudbari, University of Kharazmi, Kharazmi, Iran. E-mail: \\ esfehani.mohamad3@gmail.com
}

Received: March 2, 2016

Accepted: May 8, $2016 \quad$ Online Published: July 12, 2016

doi:10.5539/res.v8n3p187

URL: http://dx.doi.org/10.5539/res.v8n3p187

\begin{abstract}
Fan loyalty is imperative for sports clubs. In fact, fans have more trust in their favorite team will remain loyal to the team. Team managers and sports clubs must win the trust of their fans. Club brand personality is one of the variables that can be used to enhance the trust of the fans. Due to this issue, in this study, the relationship between club brand personality, trust and loyalty of fans have been investigated. The population of this research consists of Persepolis FC fans and 384 persons were evaluated as the statistical sample. To collect the data, the brand personality questionnaire by Tsiotso (2012), the modified questionnaire by Chowdhury and Holbrook (2001), the attitudinal loyalty questionnaire by Gladden and Funk (2003) and the behavioral loyalty questionnaire by Fink et al. (2001) were used. Descriptive and inferential statistics (regression coefficient and Structural Equation Modeling) were used for statistical analysis. The results of structural equation modeling revealed that club brand personality influences on brand trust and it influences behavioral and attitudinal loyalty of the fans. The managers of Persepolis FC can use a brand trust to increase the loyalty of their fans and implement brand personality to gain their trust.
\end{abstract}

Keywords: brand, brand personality, brand trust, Persepolis FC

\section{Introduction}

A brand is like an iceberg and we cannot see whole parts of it and only a small portion of it is visible. The visible part shows those things that have been associated with the brand over time. But much of it, which indicates the power of the brand is under the water and the person is not be able to find it (Gwinner \& Swanson, 2003). In sports industry, each sports team can be considered as a brand and fans can be considered as customers (Filo \& Funk, 2008). Due to this issue, paying attention to fans is inevitable (Bristow \& Sebastian, 2001). In order to take advantage of emotional commitment of fans and spectators, sports organizations and clubs design branding strategies that are based on history, values, strong personality, ability to develop products and diversifying income ways. Achieving fame and reputation does not depend only on superiority of a product, but this depends on the superiority and reputation of players and a strong history in which the club's values has been accepted (Chanavat \& Bodet, 2009). Since fans play an undeniable role in the development of economic and non-economic potentials of sports clubs, attention to this leading indicator could be helpful in strengthening the financial structure of club. The economic growth of sports industry also depends on more public attention to this phenomenon. So pay attention to customer relations and consumers of sports products should have an important place in performance of clubs (Kim \& Trail, 2011). Given the importance of fans for club, attention to loyalty of fans seems necessary. YOO and Donthu (2001) defined brand loyalty as having an orientation to stay loyal to a particular brand, which is displayed by the desire to buy from that brand as the primary choice (YOO \& Donthu, 2001). Brand loyalty is a strongly held commitment to re-purchase and support of the desired products or services and this will continue, in spite of environmental impacts and competitor's activities (Oliver, 1999). The researchers argue that re-purchase does not necessarily mean consumer loyalty, because it possible that a customer buys a product or service in a repetitive manner and shows a loyal behavior; but it is something other than attitudinal commitment to a company (Baloglu, 2002). With this in mind, researchers examined the loyalty from both behavioral and attitudinal aspects. Behavioral loyalty to purchase and use of a product over a long period implies that behavioral loyalty included some indices such as re-purchase and recommendations to other people (Clottey, Collier, \& Stodnick, 2008). Attitudinal loyalty also is considered as an effective component on 
brand loyalty. Such loyalty to a brand means customers' preference, purchase intent and long-term commitment to a specific brand; however, this kind of loyalty is profitable, when it can be led to behavioral loyalty. So, attitudinal loyalty includes indices such as commitment, trust, belonging and attachment to brand (Anisimova, 2007). The dominant role of one of the aspects of loyalty has been mentioned in some studies and the combined effect of these two aspects in the formation of loyalty has been emphasized in some other studies. In this status, a number of studies have highlighted on the impact of loyalty on repeat purchase and appropriate attitude. Considering the loyalty as the equation of "attitude-behavior", they were able to identify factors influencing the loyalty (Dich \& Basu, 1994). In a research in the area of fans, Filo and Funk (2008) suggested brand trust to sports clubs managers to increase loyalty of fans.

In marketing literature, trust is considered as a necessary precondition for building relationships with customers and influence on buying behavior (Huang \& Chu, 2011). Trust is one of the main objective of any brand. The most difficult goal of a company is to attract the trust of customers, as customer satisfaction and increasing brand trust can be effective in the future and repurchase decisions. The more the customer satisfaction, the more the customer trust and loyalty (Alam, Arshad, \& shabbir, 2012). Chaudhuri and Holbrook defined brand trust as a perception of reliability, dependability, honesty and integrity of brand (Chaudhuri \& Holbrook, 2001). Trust is the main drivers of loyalty and creates exchange relationships which have high value (Chaudhuri \& Holbrook, 2001). If the brand trust be low, satisfaction turns into an inert factor in spite of product and service satisfaction. On the contrary, brand trust can converts satisfaction into loyalty (Yoalha, 2004). Brand trust is one of the concepts that is associated with other important concepts and new marketing areas, including the concept of brand personality, which can affect the brand trust (Dewi, Saleh, \& Sampurno, 2015). The character is a fascinating topic in marketing. Aaker (1997) defines the character as one of the main aspects of brand identity and of the main variables affecting customer decision making process (Aaker, 1997). The brand personality refers to customers' describtion from a particular brand which takes place on the basis of information collected or previous experience from that brand and since a brand creates a special identity for a product, acquiring a reputable brand is one of the customers' requests in choosing a product (Baloglu, 2002). Brand personality and human personality seem to be similar in conceptual level, but they have quite different objectives. Brand is a non-human factor and does not behave like a human and the obtained perception of a personality is the result of using it by other poeple and its features such as performance (Bosnjak, Bochmann, \& Hafschmidt, 2007). As human personality, brand personality can also grow and evolve over time. Brand personality forms with respect to the activities of a brand through time and can be effective on other variables in the field of brand (Lau \& Phau, 2007).

Therefore, in this study, we will consider whether the brand personality can predict brand trust? Which components of brand personality can better predict the trust of fans? And does the trust of fans affect their loyalty? The conceptual framework is as follows:

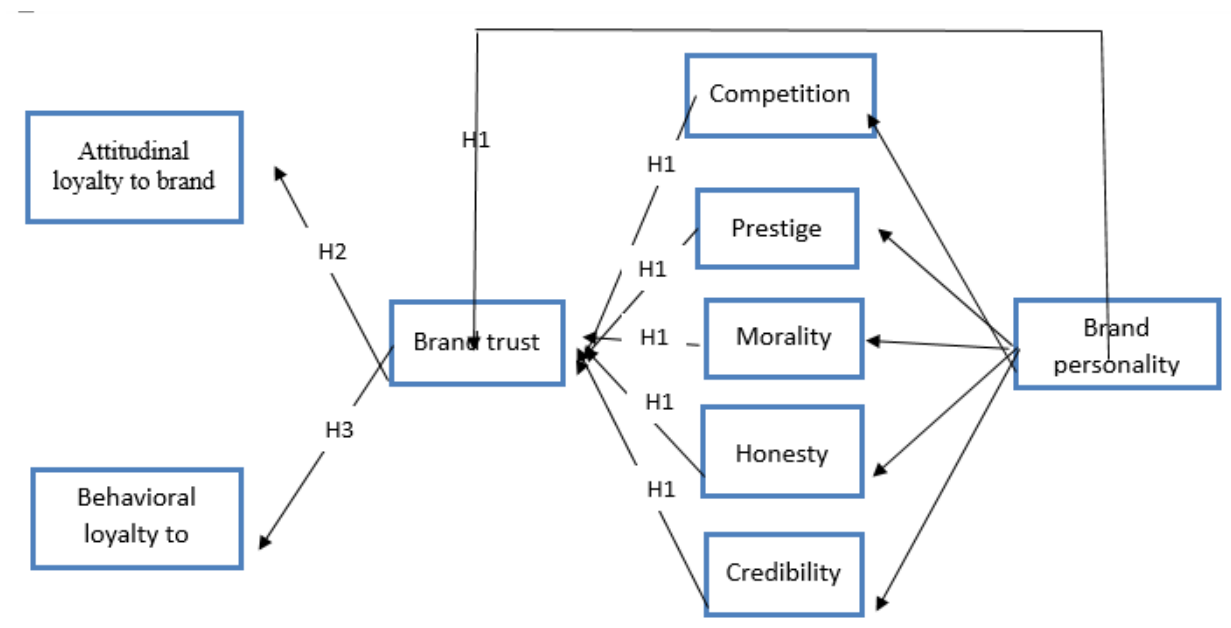

Figure 1. The conceptual framework 


\section{Method}

This is an applied study in indexes of purpose and it is a survey in terms of data collection, which is based on structural equation modeling. Data collection instrument was a questionnaire that have been compiled using information field. The research population consists of all Persepolis FC fans. Spectators who had gone to Azadi Stadium to watch one of the matches of Persepolis FC, were considered as available sample. Krejcie and Morgan table utilized to evaluate sample size. This table suggests 384 persons for large communities up to one million. To collect data, a few questionnaires were used including club's brand personality questionnaire by Tesiotso (2012) with 24 items, the modified questionnaire by Chaudhuri and Holbrook (2001) to measure brand trust with 4 items, the attitudinal loyalty questionnaire by Gladden and Funk (2001) with 3 items and behavioral loyalty questionnaire by Fink et al. (2003) with 3 items. The questionnaires were Likert 5-point scale. Expert opinions were used to determine the reliability and construct validity of the questionnaire. The Cronbach's alpha parameter utilized to measure the reliability of the questionnaire. Finally, the reliability of the questions was confirmed by the quotient obtained. Both descriptive and inferential data utiziled for data analysis. Initially, the demographic characteristics of the participants were obtained using descriptive statistics. Then, simple linear regression and structural equation modeling were used to test the hypotheses.

\section{Results}

Demographic Findings showed that most of the fans are in the age group 19 to 30 years which was 46 percent of respondents and $6 \%$ of respondents had less than 18 years old. In terms of qualification, $16 \%$ of respondents have high school diploma, $55 \%$ have secondary school degree, $13 \%$ have associate's degree, $12 \%$ have Bachelor's degree and 4\% have master's degree and above. In terms of time, $94 \%$ of respondents supported the team more than 10 years and $6 \%$ supported the team less than 10 years. $43 \%$ attend in the stadium from more than 7 years ago, while $34 \%$ go to the stadium 4 to 7 times and $23 \%$ go to the stadium less than 4 times.

Multiple regression was used to predict brand trust by the dimensions of brand personality. Table 1 indicates the characteristic of the aforementioned regression analysis. According to this table, $44 \%$ of the variance in brand trust are determined by the dimensions of brand personality.

Table 1 . The characteristic of regression analysis of the impact of brand personality on brand trust

\begin{tabular}{cccccccc}
\hline $\begin{array}{c}\text { Statistical } \\
\text { Index }\end{array}$ & - & $\begin{array}{c}\text { The correlation } \\
\text { coefficient (R) }\end{array}$ & $\begin{array}{c}\text { The coefficient } \\
\text { of determination }\end{array}$ & $\begin{array}{c}\text { Adjusted coefficient } \\
\text { of determination } \\
\text { (Adjusted Squared) }\end{array}$ & $\begin{array}{c}\text { Durbin } \\
\text { Watson }\end{array}$ & F & $\begin{array}{c}\text { Significance } \\
\text { level (Sig) }\end{array}$ \\
\hline $\begin{array}{c}\text { Regression } \\
\text { Model }\end{array}$ & 1 & 0.664 & 0.441 & 0.434 & 1.403 & 59.89 & 0.000 \\
\hline
\end{tabular}

Standard and non-standard coefficients for each of the dimensions of brand personality have been shown in Table 2 and the regression equation is written according to non-standard values in Table 2.

Brand trust $=1.835+(0.447)$ brand personality

Table 3 shows the regression coefficient of the impact of brand personality on brand trust. According to the results presented in Table 3, the regression equation to predict brand trust through brand personality can be set as follows:

$\mathrm{Y}=0.199$ (honesty) +0.146 (morality) +0.500 (Prestige)

Table 2. Standard and non-standard coefficients for each of the dimensions of brand personality with brand trust

\begin{tabular}{ccccc}
\hline Model & $\begin{array}{c}\text { B (non-standard } \\
\text { coefficients) }\end{array}$ & $\begin{array}{c}\beta \text { (standardized } \\
\text { coefficient) }\end{array}$ & $\mathrm{T}$ & $\begin{array}{c}\text { Significance level } \\
\text { (Sig) }\end{array}$ \\
\hline Constant & 0.074 & - & 0.327 & 0.744 \\
Competition & 0.082 & 0.076 & 1.378 & 0.169 \\
Prestige & 0.0500 & 0.365 & 7.159 & 0.000 \\
Morality & 0.146 & 0.172 & 3.729 & 0.000 \\
\hline
\end{tabular}




\begin{tabular}{ccccc}
\hline Honesty & 0.199 & 0.188 & 3.610 & 0.000 \\
Credibility & 0.074 & 0.083 & 1.620 & 0.106 \\
\hline
\end{tabular}

Table 3. The regression coefficients of impact of brand personality on brand trust

\begin{tabular}{cccccc}
\hline & $\begin{array}{c}\text { Non- Standardized } \\
\text { regression coefficients }\end{array}$ & Standard error & $\begin{array}{c}\text { Standardized } \\
\text { regression coefficients }\end{array}$ & $\mathrm{T}$ & $\begin{array}{c}\text { Significance } \\
\text { level }\end{array}$ \\
\hline $\begin{array}{c}\text { Constant } \\
\begin{array}{c}\text { Brand } \\
\text { personality }\end{array}\end{array}$ & 1.835 & 0.103 & & 17.749 & 0.000 \\
\hline
\end{tabular}

The above regression results indicate that there is a significant relationship between the brand personality and brand trust. Also according to non-standardized regression coefficient, we can say that in exchange for a unit change in brand personality, there would be 0.447 unit change in brand trust.

Simple linear regression was used to predict attitudinal loyalty by variable of brand trust. Table 4 indicates the characteristic of the aforementioned regression analysis.

Table 4. The characteristic of regression analysis of the impact of brand trust on attitudinal loyalty

\begin{tabular}{ccccccc}
\hline $\begin{array}{c}\text { Statistical } \\
\text { index }\end{array}$ & $\begin{array}{c}\text { The } \\
\text { correlation } \\
\text { coefficient (R) }\end{array}$ & $\begin{array}{c}\text { The coefficient } \\
\text { of determination } \\
\text { (Square) }\end{array}$ & $\begin{array}{c}\text { Adjusted coefficient } \\
\text { of determination } \\
\text { (Adjusted Squared) }\end{array}$ & $\begin{array}{c}\text { Durbin } \\
\text { Watson }\end{array}$ & F & $\begin{array}{c}\text { Significance } \\
\text { level (Sig) }\end{array}$ \\
\hline $\begin{array}{c}\text { Regression } \\
\text { Model }\end{array}$ & 0.579 & 0.356 & 0.354 & 1.336 & 21.62 & 0.000 \\
\hline
\end{tabular}

Assuming independence of errors has been confirmed considering the value of the Durbin-Watson statistic. Table 4 shows the regression coefficient impact of brand trust on attitudinal loyalty. According to the coefficient of determination $\mathrm{R} 2=0.356$, we can say that about $35 \%$ of changes in attitudinal loyalty can be explained by the brand trust.

Table 5. The regression coefficients of the impact of brand trust on attitudinal loyalty

\begin{tabular}{llllll}
\hline \multicolumn{1}{c}{$\begin{array}{c}\text { Statistical } \\
\text { index } \\
\text { Variable }\end{array}$} & $\begin{array}{c}\text { Non-Standardized } \\
\text { regression } \\
\text { coefficients }\end{array}$ & Standard error & $\begin{array}{c}\text { Standardized } \\
\text { regression } \\
\text { coefficients }\end{array}$ & T & Significance level \\
\hline Constant & 1.490 & 0.156 & - & 9.561 & 0.000 \\
$\begin{array}{l}\text { Brand } \\
\text { personality }\end{array}$ & 0.447 & 0.038 & 0.0597 & 14.547 & 0.000 \\
\hline
\end{tabular}

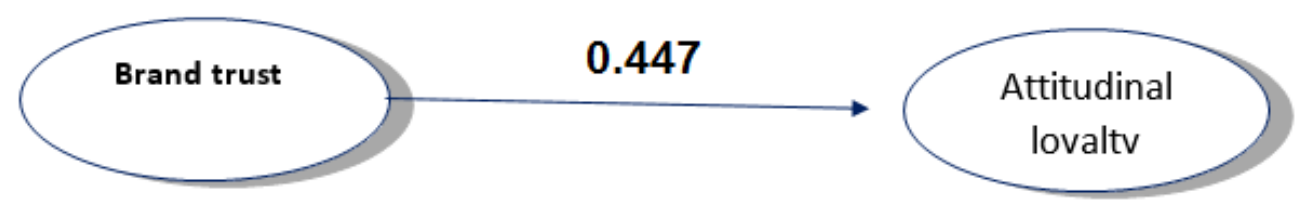

Figure 2. Diagram regression effect of brand trust on attitudinal loyalty 
The regression equation to predict attitudinal loyalty trust through brand personality can be set as follows:

Attitudinal loyalty $=1.490+(0.447)$ brand trust

The regression results in Table 5 indicate that there is a significant relationship between attitudinal loyalty and brand trust. Also according to non-standardized regression coefficient, we can say that in exchange for a unit change in brand trust, there would be 0.447 unit change in attitudinal loyalty.

Simple linear regression was used to predict attitudinal loyalty by variable of brand trust. Table 6 indicates the characteristic of the aforementioned regression analysis.

Assuming independence of errors has been confirmed considering the value of the Durbin-Watson statistic. Table 6 shows the regression coefficient impact of brand trust on behavioral loyalty. According to the coefficient of determination $\mathrm{R} 2=0.408$, we can say that about $40 \%$ of changes in behavioral loyalty can be explained by the brand trust.

Table 6 . The characteristic of regression analysis of the impact of brand trust on behavioral loyalty

\begin{tabular}{ccccccc}
\hline $\begin{array}{c}\text { Statistical } \\
\text { index }\end{array}$ & $\begin{array}{c}\text { The } \\
\text { correlation } \\
\text { coefficient (R) }\end{array}$ & $\begin{array}{c}\text { The coefficient } \\
\text { of determination } \\
\text { (Square) }\end{array}$ & $\begin{array}{c}\text { Adjusted coefficient } \\
\text { of determination } \\
\text { (Adjusted Squared) }\end{array}$ & $\begin{array}{c}\text { Durbin } \\
\text { Watson }\end{array}$ & F & $\begin{array}{c}\text { Significance } \\
\text { level (Sig) }\end{array}$ \\
\hline $\begin{array}{c}\text { Regression } \\
\text { Model }\end{array}$ & 0.639 & 0.408 & 0.407 & 1.465 & 264.33 & 0.000 \\
\hline
\end{tabular}

Table 7. The regression coefficients of the impact of brand trust on behavioral loyalty

\begin{tabular}{cccccc}
\hline & $\begin{array}{c}\text { Non-Standardized } \\
\text { regression } \\
\text { coefficients }\end{array}$ & Standard error & $\begin{array}{c}\text { Standardized } \\
\text { regression } \\
\text { coefficients }\end{array}$ & $\mathrm{T}$ & Significance level \\
\hline $\begin{array}{c}\text { Constant } \\
\text { Brand }\end{array}$ & 1.635 & 0.131 & & 12.471 & 0.000 \\
personality & 0.447 & 0.035 & 0.639 & 16.255 & 0.000 \\
\hline
\end{tabular}

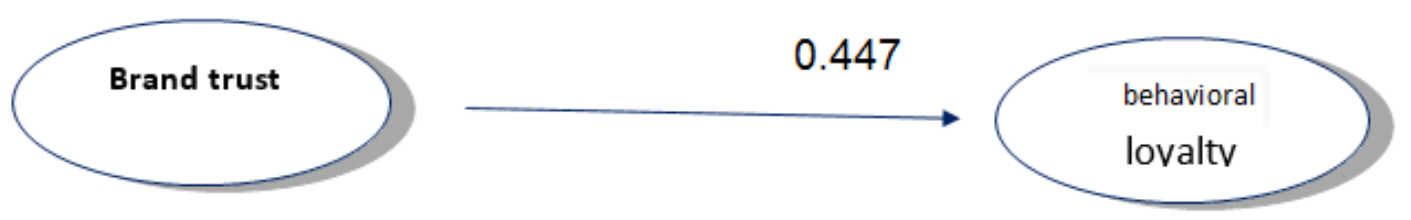

Figure 3. Diagram regression effect of brand trust on behavioral loyalty

The regression equation to predict behavioral loyalty through brand trust can be set as follows:

Behavioral loyalty $=1.635+(0.447)$ brand trust

The regression results in Table 7 indicate that there is a significant relationship between behavioral loyalty and brand trust. Also according to non-standardized regression coefficient, we can say that in exchange for a unit change in brand trust, there would be 0.447 unit change in behavioral loyalty.

The final structural equation modeling was used to assess the relationship between three of the main structures of this study, which are brand personality, brand trust and loyalty of fans. Since the brand personality is made by some latent variable, therefore, according to the statements, it is used as visible variable in the final model. The results also show that structural model of the impact of brand personality on brand trust and brand loyalty of the fans has enough fitness. The results of structural equation modeling in Figure 4 shows that the brand personality has an influence on brand trust and brand trust also affects behavioral and attitudinal loyalty. 


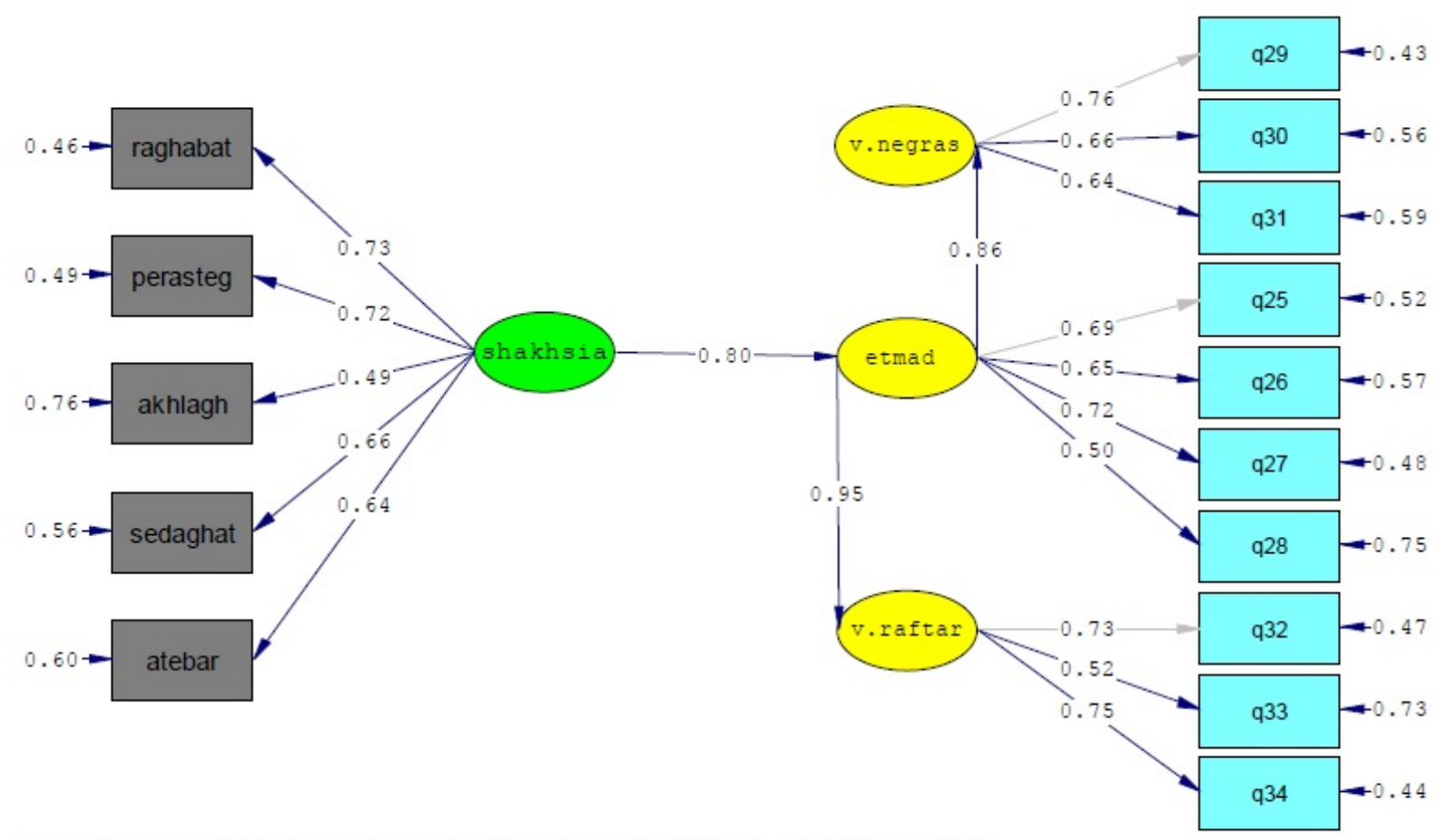

Chi-Square=280.77, df=87, P-value=0.00000, RMSEA=0.076

Figure 4 . The results confirmed of the final research model

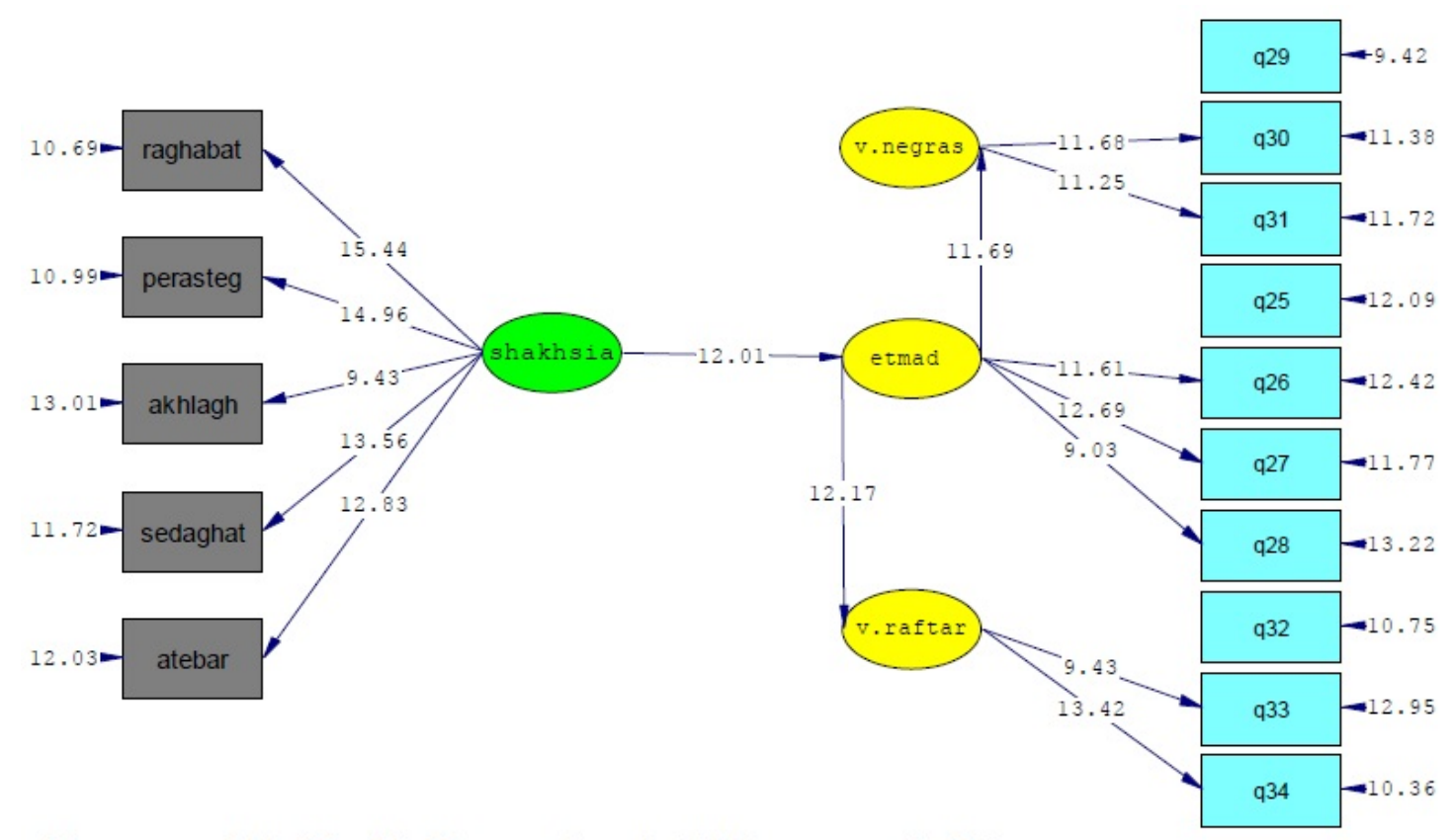

Chi-Square=280.77, df=87, P-value=0.00000, RMSEA $=0.076$

Figure 5. T-value results confirmed of the final research model 


\section{Discussion}

Since several studies suggest that brand personality leads to brand trust and therefore, brand trust results in customer loyalty. Therefore, this research wants to evalute the interaction between club's brand personality, brand trust and loyalty of Persepolis FC's fans. The consequences of structural equation modeling exposed that club brand personality impacts on brand trust, and it affects behavioral and attitudinal loyalty of the fans. The administrators of Club can use a brand trust to strengthen the faith of their fans and implement brand personality to get their support.

The regression coefficient results showed among dimensions of brand personality, only prestige, morality and honesty have the ability to predict the brand trust. Based on the parametre of measured $\mathrm{R} 2=0.412$, we can say that about $40 \%$ of changes in brand trust can be explained by the brand personality. In addition, the results of structural equation modeling showed that the brand personality has an influence on fan's brand trust. These results are consistent with results of Devi et al. (2015), Perepelkin and Zhang (2011), Zuhroh and Rofiaty (2014), Sabrina (2011), Nili et al. (2013). Much research in this area indicates the importance of this issue. According to current findings, it should be understood that in Persepolis FC, prestige, morality and honesty dimensions of brand personality and the brand personality itself, generaly, are the most important variables which are related to fan's brand trust. Therefore, Persepolis FC should pay more attention to the things that create a team with a better character compared to other clubs in order to gain the trust of fans. A brand personality is achieved by contact between the consumer and the brand. For this reason, Persepolis FC should pay more attention to the relationship with the fans in order to build brand personality. In fact, Persepolis FC should liaise with fan via items such as relationship marketing, fan clubs, websites, answering phones and so on. As a result, brand personality is created by the relationship between the fans and the club and leads to greater trust from the fans. According to the results, the prestige dimension of brand personality has the highest ability to predict the trust of fans. Therefore, Persepolis FC can emphasize on number of fans and the earned honors compared to rival teams (for example, presence in the Asian Champions League and the Premier League title of Iran). In addition, Persepolis FC can hire famous players and outstanding coaching staff. In these circumstances, the prestige of the club be very well understood by the fans and their trust increases. Trust as the main essence of marketing, can underlies success and failure of different organizations. Although little research has been carried out on the relationship between the brand personality and fan's trust in sports clubs; however, it can be concluded that if the brand personality increases, the fan's trust also will increase. It should be noted that there isn't any inconsistent research with this result. This shows the importance of brand personality as a key factor in predicting fan's trust. As a result, managers and club owners should upgrade their brand personality in order to increase trust in the fans and customers. This could be very important, because trust in fans and customers can be used as a competitive tool that leads to returning the fans and customers loyalty. As initially mentioned, many studies have not been done in sports, especially football fans and the relationship between these two variables is not clear yet. For this reason, more research can help managers to identify factors associated with decisions on customers' behavior, especially their trust. This could be very important in terms of sources of revenue for clubs. The regression coefficient impact of brand trust on attitudinal loyalty obtained and the coefficient of determination is equal to R $2=0.356$, we can say that about $35 \%$ of changes in attitudinal loyalty can be explained by the brand trust. The regression coefficient impact of brand trust on behavioral loyalty obtained and the coefficient of determination is equal to $\mathrm{R} 2=0.408$, we can say that about $40 \%$ of changes in behavioral loyalty can be explained by the brand trust. Results related to structural equation modeling showed that brand trust affects attitudinal and behavioral loyalty.

The findings of this section of the research is consistent research results Bhakar (2015), Choi and Hyun (2011) and Geçti (2013) who believe that brand trust is a major issue for increasing the attitudinal and behavioral loyalty. According to current findings, it should be understood that for the Persepolis Club brand trust is an important element that would lead to fan's attitudinal and behavioral loyalty. In marketing literature, trust is a necessary precondition for building relationships with customers and has an influence on consumers' purchasing behavior. Sports teams cannot always remain in good condition. They dumped into fluctuate during the season resulting in better sports teams take their team to win the trust of fans. This trust can help them when the team is faltering and continues to keep fans loyal to the team. Persepolis FC has fluctuated in recent years and managers of the club can discover the factors that create trust in fans and thereby keep fans loyal to the team. Filho et al. (2008) as a result of research conducted in the field of sports teams fans, suggested to managers that pay special attention to brand trust and through social responsibility, consumer satisfaction and quality customer service, try to increase brand trust and loyalty of the fans. According to the results of Filho et al. (2008), the managers of Persepolis FC can also use these items to increase brand trust. For example, social responsibility projects (such 
as charitable games, visiting team players and technical staff from places such as elderly and disabled nursing home, helping a charity sites), the quality of of their team and the fans satisfaction. According to the results, there is a relationship between the brand personality and the trust of the fans. The managers of Persepolis FC can earn the trust of fans through compliance with laws and regulations, financial independence, honesty with fans, eye-catching games and highlighting the glory and fame of Persepolis. The results of Shih-Hao et al. (2012) showed that brand trust affects loyalty of fans. They recommended to sports organizations that they should vastly invest in activities which have long-term effects on trust, not short-term strategies. Since the brand personality is preserved for a long time and hardly changes, Persepolis FC be recommended that pay special attention to its own brand character in order to increase trust in the fans. Results in this section were in line with the results of Nili and colleagues (2013) and Sabrina (2011) and it is due to a difference in the community, because the companies that were analyzed in previous studies, had factors that are not comparable with FCs and Fans. This research has been done in other industries apart from sports teams and these industries may be affected customer trust and trust in customers wiped out by various factors. When fans trust heavily on their favorite team, this trust simply will not go away. Fans establish an emotional relationship with their favorite team. This relationship prevents a reduction in the trust. There is enough fitness in the impact of brand personality on brand trust and brand loyalty. In other words, it can be said that there is a causal relationship between brand personality, brand trust and loyalty of the fans. Because there is no detailed information about supporters in FCs, it is impossible for us to provide a consistent model for football fans in Iran. The number of studies should be increased in order to prove the validity of this model. Since the demographic variables and intermediate variables have not been evaluated, we cannot talk about verifying the model. With these explanations, it must be said that if all the conditions are correct and nuisance and modulators factors be quite low, the model has good stability. The good fit in the research variables (Brand personality, brand trust and attitudinal and behavioral loyalty) proves this issue.

Overall, the results show that brand personality can predict brand trust and brand loyalty and brand trust can predict brand loyalty. So, managers and directors of Persepolis FC are recommended that they should pay more attention to their club's brand personality. Brand personality can have an impact on brand trust and brand trust leads to brand loyalty.

\subsection{Practical Suggestions}

Considering the impact of brand personality on brand trust, to increase the trust of the fans, Persepolis FC should pay special attention to factors that increase club brand personality (such as dealing honestly with fans, emphasizing the number of fans and trophies, enhance the attractiveness and quality of the games, presence of star players in the team).

Because the brand trust is effective on brand loyalty, the managers of Persepolis FC are recommend to pay special attention to brand trust and consider its special role in communication management and design appropriate strategies and programs to develop customer trust.

In order to increase the trust of fans, the managers of Persepolis FC be suggested to implement features such as social responsibility, satisfying fans, quality service to fans, devotion and commitment to the brand and brand personality.

\subsection{Suggestions for Future Research}

Because many factors involved in predicting and explaining a variable, it is proposed that a study be carried out that be similar to the increase in mediating variables (such as attachment and commitment to the brand).

Considering that this study was limited to the fans in Tehran and since Persepolis FC has a lot of fans across the country, it is suggested that similar studies be carried out at national level.

\section{References}

Aaker, A. D. (1997). Dimentions of brand personality. Journal of marketingresearch, 34, 347-356. http://dx.doi.org/10.2307/3151897

Alam, A., Arshad, M. U., \& Shabbir, S. A. (2012). Brandcredibility, customer loyalty and therole of religious orientation. Asiapacific. Journal of marketing and logistics, 24(4), 583-598. http://dx.doi.org/10.1108/13555851211259034

Anisimova, T. A. (2007). The effects of corporate brand attributes and behavioral consumer loyalty. Journals of Consumer Marketing, 24(7). 
Baloglu, S. (2002). Dimensions of customer Loyalty: Separating friends from well wishers (Vol. 43, No. 1). http://dx.doi.org/10.1016/s0010-8804(02)80008-8

Bhakar, S. (2015). Impact of Brand Reputation on Attitudinal Loyalty and Behavioral Loyalty with Brand Trust as Mediating Variable (Vol. 4, pp. 11-15).

Bodet, G., \& Chavanat, N. (2010). Building global brand equity: Lessons from the Chinese market. Asia Pacific Journal of Marketing and Logistics, 22(1), 55-66. http://dx.doi.org/10.1108/13555851011013155

Bosnjak, V., Bochmann, M., \& Hafschmidt, T. (2007). Dimensions of brand personality attribution: A person-centric approach in the german cultural context. Social behavior and personality, 35(3), 303-316. http://dx.doi.org/10.2224/sbp.2007.35.3.303

Bristow. D. N., \& Sebastian, R. J. (2001). Holy cow! Wait' till next year! A closer look at the brand loyalty of Chicago cubs baseball fans. Journal of Consumer Marketing, 18, 256-275. http://dx.doi.org/10.1108/07363760110392976

Chaudhuri, A., \& Holbrook, M. (2001). The Chain of Effects from Brand Trust and Brand Affect to Brand Performance: The Role of Brand Loyalty. Journal of Marketing, 65(2), 81-93. http://dx.doi.org/10.1509/jmkg.65.2.81.18255

Choi, Y. G., Ok, C., \& Hyun, S. S. (2011). Evaluating relationships among brand experience, brand personality, brand prestige, brand relationship quality, and brand loyalty: An empirical study of coffeehouse brands.

Clottey T. A., Collier D. A., \& Stodnick, M. (2008). Drivers of customer loyalty in retail store environment. Journal of Service Science, 1, 56-62.

Dewi, Y. L., Saleh, S., \& Sampurno. (2015). The Effect of Brand Personality and Trust on Kiranti's Brand Loyalty. Journal Manajemen dan Pelayanan Farmasi (JMPF), 5, 34-43.

Dick, A. S., \& Basu, K. (1994). Consumer loyalty: Toward an integrated conceptual approach. Journal of Academy of Marketing Science, 22(2), 124-131. http://dx.doi.org/10.1177/0092070394222001

Filo, K., \& Funk, D. C. (2008). Exploring the role of brand trust in the relationship between brand associations and brand loyalty in sport and fitness. Internasional journal sport management and marketing, 3, 39-54. http://dx.doi.org/10.1504/IJSMM.2008.015960

Geçti, F., \& Zengin, H. (2013). The Relationship between Brand Trusts, Brand Affect, Attitudinal Loyalty and Behavioral Loyalty (2013): A Field Study towards Sports Shoe Consumers in Turkey. International Journal of Marketing Studies.

Gwinner, K., \& Swanson, S, R. (2003). A model of fan identification antecedents and sponsorship outcomes. Journal of service marketing, 17(3), 275-294. http://dx.doi.org/10.1108/08876040310474828

Hadiwidjoyo, Z., \& Djumahir, D. R. (2014). The Role of Brand Personality Concongruity (BPC) on Brand Loyalty Mediated by Customer Value and Brand Trust (Study on Bon Blackberry Smartphone Users). European Journal of Business and Management, 6, 289-296.

Hong, I., \& Cho, H. (2011). The impact of consumer trust on attitudinal loyalty and purchase intentions in B2C e-marketplaces: Intermediary trust vs. seller trust. International Journal of Information Management, 31, 469-479. http://dx.doi.org/10.1016/j.ijinfomgt.2011.02.001

Kim, Y. K., \& Trail, G. (2011). Constraints and motivators: A new model to explain sport consumer behavior. Journal of Sport Management, 24(2), 190-210.

Lau, K. C., \& Phau, I. (2007). Extending symbolic brand using their personality: Examining ahtecedents and implications towards brand image fit and brand dilution. Psychology marketing, 24(5), 421-444. http://dx.doi.org/10.1002/mar.20167

Nili1, M., Navabakhsh, M., \& Khosropour, A. (2013). Influence of Corporate Reputation and Brand Personality on Customer Satisfaction and Loyalty in Communication Services. Technical Journal of Engineering and Applied Sciences.

Oliver, R. L. (1999). Whenc econsumer Loyalty? Journal of marketing, 63(1), 33-43. http://dx.doi.org/10.2307/1252099

Perepelkin, J., \& Zhang, D. (2011). Brand personality and Brandpersonality and pharmacies. International Journal of Pharmaceutical and Healthcare Marketing, 5, 175-193. http://dx.doi.org/10.1108/17506121111172194 
Sabrina, Y. A. (2011). Brand Influence of Personality on Brand Trust, Attachment Brand, Brand Commitment, and Brand Loyalty. Jurnal Bisnis dan Ekonomi (JBE), 18(2), 114-125.

Wu, S.-H., Tsai, C.-Y. D., \& Hung, C. C. (2012). Toward Teamteam or Player? How Trust, Vicarious Achievement Motive, and Identification Affec Fan fan Loyalty. Journal of Sport Management, 26, 177-191.

Yoal ha, H. (2004). Factors influencing consumer perception of brand trust. Online Journal of Product \& Brand Management, 13, 329-342.

Yoo, B., \& Donthu, N. (2001). Developing and validating a multidimensional consumer-based brand equity scale. Journal of Business Research, 53, 1-14. http://dx.doi.org/10.1016/S0148-2963(99)00098-3

\section{Copyrights}

Copyright for this article is retained by the author(s), with first publication rights granted to the journal.

This is an open-access article distributed under the terms and conditions of the Creative Commons Attribution license (http://creativecommons.org/licenses/by/3.0/). 